\title{
Household transmission of SARS-CoV-2 R.1 lineage with spike E484K mutation in Japan
}

Yosuke Hirotsu $^{1 *}$ and Masao Omata ${ }^{2,3}$

${ }^{1}$ Genome Analysis Center, Yamanashi Central Hospital, 1-1-1 Fujimi, Kofu, Yamanashi, Japan

${ }^{2}$ Department of Gastroenterology, Yamanashi Central Hospital, 1-1-1 Fujimi, Kofu, Yamanashi, Japan

${ }^{3}$ The University of Tokyo, 7-3-1 Hongo, Bunkyo-ku, Tokyo, Japan

*Corresponding author: Yosuke Hirotsu, Genome Analysis Center, Yamanashi Central Hospital, 1-1-1 Fujimi, Kofu, Yamanashi, Japan

Email: hirotsu-bdyu@ych.pref.yamanashi.jp

Tel: +81-55-253-7111, Fax: +81-55-253-8011

ORCID ID: 0000-0002-8002-834X

Running title: Household transmission of SARS-CoV-2 R.1 lineage

Keywords: SARS-CoV-2; COVID-19; genome; E484K; R.1 lineage 


\section{Abstract}

We aimed to investigate SARS-CoV-2 emerging lineage harboring variants in receptor binding domain (RBD) of spike protein in Japan. Total nucleic acids were subjected to whole genome sequencing on samples from 133 patients with coronavirus disease (COVID-19). We obtained the SARS-CoV-2 genome sequence from these patients and examined variants in RBD. As a result, three patients were infected with SARS-CoV-2 harboring E484K mutation in January 2021. These three patients were relatives; one was in the 40 s, and two were younger than 10 years old. They had no history of staying abroad and were living in Japan. This strains were classified into GR clade (GISAID), 20B clade (Nextstrain) and R.1 lineage (PANGO). As of March 5, 2021, the R.1 lineage have been identified in 305 samples and dominantly observed in the USA (44\%, 135 / 305) and Japan (28\%, 84 / 305) from the GISAID database. During the period between October 26, 2020 and February 23,2021 , the frequency of the R.1 lineage was $0.97 \%(84 / 8,629)$ of the total confirmed data in Japan and $0.15 \%(135 / 90,450)$ in the USA. Although SARS-CoV-2 R.1 lineage was not globally predominant as of March 2021, further analysis is needed to determine whether R.1 variant will disappear or expand in the future. 


\section{Introduction}

SARS-CoV-2 has the largest genome (29.9 kb in length) among RNA viruses. The virus encodes an exoribonuclease with a $3^{\prime}-5^{\prime}$ proofreading function, resulting in slow evolution and lower mutation rate than other RNA viruses [1, 2]. Most occurring mutations are likely to neutral during the evolution and not to influence viral properties. However, some of the mutations are selected due to the change of viral fitness, virulence and transmissibility $[3,4]$. In fact, several SARS-CoV-2 variants of concern have emerged within the last few months, especially in three major lineages (B.1.1.7, B.1.351, and P.1) [5-7]. These emerging lineages are characterized by multiple mutations in spike proteins, raising concerns that they may escape monoclonal antibody-therapy or vaccine-elicited antibodies. The B.1.1.7 lineage is estimated to have emerged in late September 2020 and rapidly became the dominant strain in the United Kingdom [5, 8, 9]. The B.1.351 lineage rapidly became the dominant strain in South Africa where it was first detected in October 2020 [6]. P.1 lineage was first identified in four travelers from Brazil and has been associated with cases of reinfection $[7,10]$.

The hallmark mutation of B.1.1.7, B.1.351, and P.1 is N501Y located in the receptor binding domain (RBD) of the spike protein [5]. The N501Y variant is thought to be more transmissible and possibly more virulent $[8,11-14]$. The other hallmark mutation of B.1.351, and P. 1 is E484K, which is related to reduce the neutralizing activity of antibodies and raising the concerns about vaccine efficacy [15-20].

In this study, we conducted genetic surveillance and identified R.1 lineage harboring E484K mutation in RBD by whole genome sequencing. The R.1 lineage was observed in three patients and transmitted among relatives in Japan. 


\section{Methods}

\section{Patients and sample collection}

A total of 166 COVID-19 patients were confirmed in our hospital, from which 133 were selected for subsequent genome analysis. Nasopharyngeal swab samples were collected using cotton swabs and placed in $3 \mathrm{~mL}$ of viral transport media (VTM) purchased from Copan Diagnostics (Murrieta, CA, USA). We used $200 \mu \mathrm{L}$ of VTM for nucleic acid extraction within $2 \mathrm{~h}$ of sample collection.

\section{Viral nucleic acid extraction}

Total nucleic acid was isolated from the samples using the MagMAX Viral/Pathogen Nucleic Acid Isolation Kit (Thermo Fisher Scientific, Waltham, MA, USA) on the KingFisher Duo Prime System (Thermo Fisher Scientific) as we previously described [21, 22]. Briefly, we added $200 \mu \mathrm{L}$ of VTM, $5 \mu \mathrm{L}$ of proteinase $\mathrm{K}, 265 \mu \mathrm{L}$ of binding solution, 10 $\mu \mathrm{L}$ of total nucleic acid-binding beads, $0.5 \mathrm{~mL}$ of wash buffer, and $0.5-1 \mathrm{~mL}$ of $80 \%$ ethanol to each well of a deep-well 96-well plate. Nucleic acids were eluted with $70 \mu \mathrm{L}$ of elution buffer.

\section{Quantitative reverse transcription polymerase chain reaction (RT-qPCR)}

Following the protocol developed by the National Institute of Infectious Diseases (NIID) in Japan [23], we performed one-step RT-qPCR to detect SARS-CoV-2. This PCR amplifies the nucleocapsid ( $N$ ) gene of SARS-CoV-2 (NC_045512.2). For the internal positive control, the human ribonuclease P protein subunit p30 (RPP30) gene was used (Integrated DNA Technologies, Coralville, IA, USA). RT-qPCR assays were conducted on a StepOnePlus Real-Time PCR System (Thermo Fisher Scientific) with the following cycling 
conditions: $50^{\circ} \mathrm{C}$ for $5 \mathrm{~min}$ for reverse transcription, $95^{\circ} \mathrm{C}$ for $20 \mathrm{~s}$, and 45 cycles of $95^{\circ} \mathrm{C}$ for $3 \mathrm{~s}$ and $60^{\circ} \mathrm{C}$ for $30 \mathrm{~s}$. The absolute copy number of viral loads was determined using a serial diluted DNA control targeting the $N$ gene of SARS-CoV-2 (Integrated DNA Technologies) as previously described [24, 25].

\section{Whole genome sequencing}

SARS-CoV-2 genomic DNA was amplified using the Ion AmpliSeq SARS-CoV-2 Research Panel consisting of two primer pools covering $99.7 \%$ of the viral genome (Thermo Fisher Scientific) [26]. Extracted nucleic acids were subjected to genome sequencing on the Ion Torrent Genexus System according to the manufacturer's instruction. Sequencing reads and quality were processed on Genexus Software with SARS-CoV-2 plugins. The sequencing reads were mapped and aligned on the reference genome of SARS-CoV-2 strain Wuhan-Hu-1 using the torrent mapping alignment program (TMAP). After initial mapping, a variant call was performed using the Torrent Variant Caller. The COVID19AnnotateSnpEff plugin was used for annotation of variants. Assembly was performed with the Iterative Refinement Meta-Assembler (IRMA) [27], which produced the FASTA file.

\section{The clade and lineage classification}

The viral clade and lineage were conducted using the Global Initiative on Sharing Avian Influenza Data (GISAID) database [28], Nextstrain [29] and Phylogenetic Assignment of Named Global Outbreak Lineages (Pangolin; https://cov-lineages.org/index.html) [30]. The sequence of the identified R.1 variant was deposited to the GISAID EpiCoV database (Accession No. EPI_ISL_1164927, EPI_ISL_1164928 and EPI_ISL_1164929). 
Global sequencing data of the R.1 variant was exported from the GISAID EpiCoV database on March 5, 2021. We searched 305 available metadata of R.1 lineage between October 26, 2020 and February 23, 2021. We also searched a total number of samples as following parameter: lineage "R.1", host "human", location "Asia / Japan" or "North America / USA", collection date "October 26, 2020 to February 23, 2021". During this period, a total of 8,629 samples were registered in Japan, and 90,450 samples were registered in the USA.

\section{Ethical statement}

The Institutional Review Board of the Clinical Research and Genome Research Committee at Yamanashi Central Hospital approved this study and the use of an opt-out consent method (Approval No. C2019-30). The requirement for written informed consent was waived owing to the observational study and the urgent need to collect COVID-19 data. Participation in the study by patients was optional. All methods were performed in accordance with the relevant guidelines and regulations and with the Helsinki Declaration.

\section{Results}

\section{Household transmission of SARS-CoV-2 spike E484K}

To conduct the genomic surveillance, we have started to investigate the variants in RBD of spike protein in Kofu city, Japan [26]. The nucleic acids were stored at our hospital were subjected to whole genome analysis.

We previously identified the P.1 lineage harboring K417T/ E484K / N501Y in a patient [26]. Subsequently, consecutive analysis detected spike E484K mutation in three patients. The samples were collected from these patients in January 2021. These patients were relatives of each other; one was in the 40 s, and two were younger than 10 years old. 
They had no history of staying in foreign countries and lived in Japan. Around the same time, another relative was also infected with SARS-CoV-2, but the samples could not be available because the relative was tested at another hospital. These results suggested they were infected with the same virus lineage and household transmission was occurred.

\section{Genetic characterization was consistent with R.1 lineage}

Sequencing analysis identified 21 variants in total, including 13 missense, 6 synonymous and two intergenic variants. There were four missense mutations in spike protein (W152L, E484K, D614G, G769V), four in orf1ab (T4692I, N6301S, L6337M, I6525T), one in membrane protein (F28L) and four in nucleocapsid protein (S187L, R203K, G204R and Q418H).

To examine the phylogeny based on genetic variations, we analyzed genomic data using GISAID, Nextstrain and Pangolin. The sequence was assigned as GR clade (GISAID), 20B clade (Nextstrain) and R.1 lineage (PANGO). R.1 lineage is the sublineage of B.1.1.316 (github.com/cov-lineages/pangolin).

\section{Epidemiological event of R.1 lineage}

To investigate the global distribution of R.1 lineage, we next collected registration data from the EpiCoV of GISAID database [28]. As of March 5, 2021, a total of 305 samples of R.1 lineage had been registered from all over the world, with the majority spread in the USA $(44 \%, 135 / 305)$ and Japan $(28 \%, 84 / 305)$ (Figure $1 \mathrm{~A}$ and Table 1). R.1 lineage was first reported in Texas, USA at the end of October 2020, and was found in Japan at the end of November 2020. The number of detected lineages has changed in a similar trend between the USA, Japan and other countries (Figure 1A), implying that SARS-CoV-2 R.1 lineage 
medRxiv preprint doi: https://doi.org/10.1101/2021.03.16.21253248; this version posted March 20, 2021. The copyright holder for this preprint (which was not certified by peer review) is the author/funder, who has granted medRxiv a license to display the preprint in perpetuity.

It is made available under a CC-BY-NC-ND 4.0 International license .

may have emerged in several regions at approximately the same time.

The overall detection frequency was $0.97 \%(84 / 8,629)$ in Japan and $0.15 \%(135 /$ $90,450)$ in the USA over the observed period. The frequency of weekly data showed an increase from mid-January to early February 2021 in Japan and from early February to early March in the USA (Figure 1B). The frequency of the Japanese data is not available because the any data was not registered after 13 February 2021 , but it is possible that R. 1 lineage is gradually increasing in Japan.

\section{Discussion}

The development and approval of a safe and effective vaccine against SARS-CoV-2 give us a great hope eliminating the virus. Vaccines have been approved in many countries within a year and this event is an unprecedented scientific achievement [31]. On the other hand, mutations in RBD are of great concern because of the potential for immune escape.

Actually, many neutralizing antibodies involving the RBD or the $\mathrm{N}$-terminal domain [32]. Most convalescent sera and mRNA vaccine-elicited sera had reduced neutralizing activity against SARS-CoV-2 containing the E484K spike mutation [18-20]. Mutations in the RBD result in tighter binding of ACE2, allowing it to escape extensive neutralization of monoclonal antibodies mainly by E484K [33].

In Brazil, patients were re-infected with the virus carrying the E484K mutation, which is supported by the evidence that E484K is related to escape neutralizing antibodies in recovered patients. Recently, the E484K mutation present in another SARS-CoV-2 variant of concern (B.1.526) identified in New York [34, 35]. In this study, R.1 lineage harboring E484K mutation was identified in three family members in Japan. The circulating trend of 
R.1 lineage showed similar pattern in each country, implying that the ancestral strain acquired a homegrown variant almost simultaneously, and subsequently R.1 lineage are likely to emerge.

The SARS-CoV-2 acquired around one or two mutations per month. This seems to be very slow. However, the more the virus circulates in population, the more opportunity it has to change [36]. Almost half of all genome sequences are deposited from the United Kingdom in the GISAID database [31]. However, not enough samples have been sequenced in many countries, therefore, new emerging strain have been missed possibly. Therefore, the identification of mutants by genomic surveillance in real time will provide us with important insights into the effectiveness of vaccines, the development of antibody therapy and public health.

\section{Acknowledgments}

This study was supported by a Grant-in-Aid for the Genome Research Project from Yamanashi Prefecture (to M.O. and Y.H.), the Japan Society for the Promotion of Science (JSPS) KAKENHI Early-Career Scientists JP18K16292 (to Y.H.), a Grant-in-Aid for Scientific

Research (B) $20 \mathrm{H} 03668$ (to Y.H.), a Research Grant for Young Scholars (to Y.H.), the YASUDA Medical Foundation (to Y.H.), the Uehara Memorial Foundation (to Y.H.), and Medical Research Grants from the Takeda Science Foundation (to Y.H.). We thank Hitoshi Mochizuki for applying for the ethics committee. We also thank Masato Kondo, Ryota Tanaka, and Kazuo Sakai (Thermo Fisher Scientific) for technical help, all of the medical and ancillary hospital staff, and the patients for their participation.

\section{Competing Interests Statement.}


medRxiv preprint doi: https://doi.org/10.1101/2021.03.16.21253248; this version posted March 20, 2021. The copyright holder for this preprint (which was not certified by peer review) is the author/funder, who has granted medRxiv a license to display the preprint in perpetuity.

It is made available under a CC-BY-NC-ND 4.0 International license .

The authors declared no conflict of interest 
medRxiv preprint doi: https://doi.org/10.1101/2021.03.16.21253248; this version posted March 20, 2021. The copyright holder for this preprint (which was not certified by peer review) is the author/funder, who has granted medRxiv a license to display the preprint in perpetuity. It is made available under a CC-BY-NC-ND 4.0 International license.

Table 1. Frequency of R.1 strains across countries

\begin{tabular}{ccc}
\hline Country & $\begin{array}{c}\text { Number of confirmed } \\
\text { cases }(n=305)\end{array}$ & Frequency \\
\hline USA & 135 & $44 \%$ \\
\hline Japan & 84 & $28 \%$ \\
\hline Austria & 25 & $8 \%$ \\
\hline Belgium & 16 & $5 \%$ \\
\hline UnitedKingdom & 14 & $5 \%$ \\
\hline Netherlands & 11 & $4 \%$ \\
\hline Ghana & 7 & $2 \%$ \\
\hline Canada & 3 & $1 \%$ \\
\hline Australia & 3 & $1 \%$ \\
\hline Nigeria & 1 & $0.3 \%$ \\
\hline UnitedArabEmirates & 1 & $0.3 \%$ \\
\hline France & 1 & $0.3 \%$ \\
\hline Denmark & 1 & $0.3 \%$ \\
\hline Finland & 1 & $0.3 \%$ \\
\hline Switzerland & 1 & $0.3 \%$ \\
\hline Aruba & 1 & $0.3 \%$ \\
\hline Total & 305 & $100 \%$ \\
\hline
\end{tabular}


Figure 1

(A)

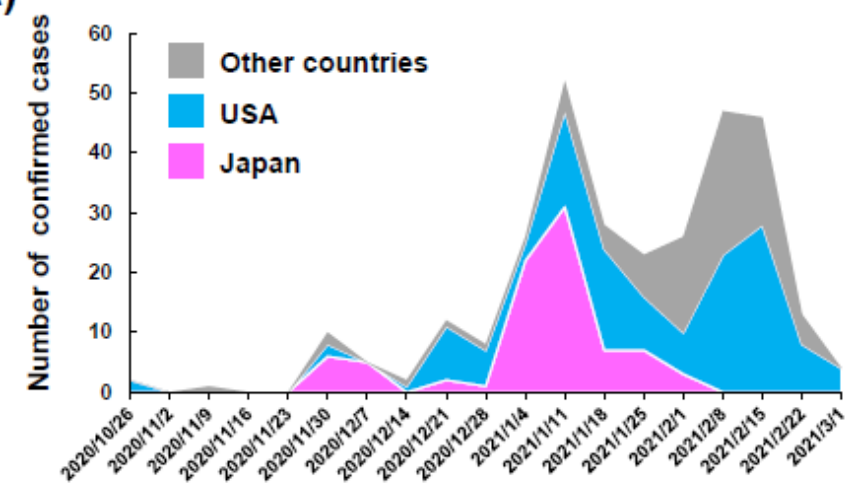

(B)
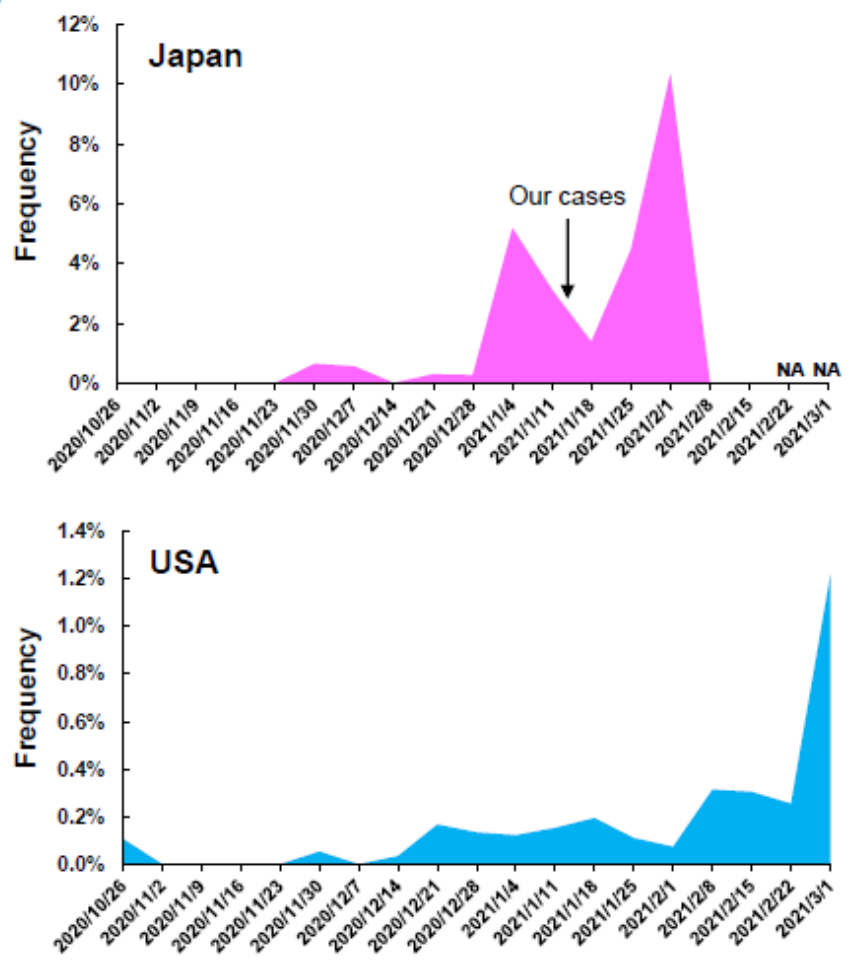

Timeline and frequency of emergence of R.1 lineage in the world

(A) Timeline of the number of confirmed cases of R.1 lineage. The plot indicates data for Japan (pink), the USA (light blue), and other countries (gray). This plot was created based on the data in Table 1. (B) The frequency of R.1 strains relative to the total number of 
registered samples during the period is shown for Japan (upper panel) and the USA (lower panel). The arrow indicates the time of infection of the three individuals identified in this study. NA, not applicable.

\section{Reference}

1. Ogando NS, Ferron F, Decroly E, Canard B, Posthuma CC, Snijder EJ: The Curious Case of the Nidovirus Exoribonuclease: Its Role in RNA Synthesis and Replication Fidelity. Frontiers in Microbiology 2019, 10(1813).

2. Duchene S, Featherstone L, Haritopoulou-Sinanidou M, Rambaut A, Lemey $P$, Baele G: Temporal signal and the phylodynamic threshold of SARS-CoV-2. Virus Evolution 2020, 6(2).

3. Hou YJ, Chiba S, Halfmann P, Ehre C, Kuroda M, Dinnon KH, Leist SR, Schäfer A, Nakajima N, Takahashi $\mathrm{K}$ et al: SARS-CoV-2 D614G variant exhibits efficient replication ex vivo and transmission in vivo. Science 2020, 370(6523):1464-1468.

4. Graham RL, Becker MM, Eckerle LD, Bolles M, Denison MR, Baric RS: A live, impaired-fidelity coronavirus vaccine protects in an aged, immunocompromised mouse model of lethal disease. Nat Med 2012, 18(12):1820-1826.

5. Andrew R, Nick L, Oliver P, Wendy B, Jeff B, Alesandro C, Tom C, Tom P, David LR, Erik $V$ et al: Preliminary genomic characterisation of an emergent SARS-CoV-2 lineage in the UK defined by a novel set of spike mutations. virological 2020.

6. Tegally H, Wilkinson E, Giovanetti M, Iranzadeh A, Fonseca V, Giandhari J, Doolabh D, Pillay S, San EJ, Msomi N et al: Emergence and rapid spread of a new severe acute respiratory syndrome-related coronavirus 2 (SARS-CoV-2) lineage with multiple spike mutations in South Africa. medRxiv 2020:2020.2012.2021.20248640.

7. Nuno R. Faria, Ingra Morales. Claro, Darlan. Candido, Lucas A. Moyses Franco, Pamela S. Andrade, Thais M. Coletti, Camila A. M. Silva, Flavia C. Sales, Erika R. Manuli, Renato S. Aguiar et al: Genomic characterisation of an emergent SARS-CoV-2 lineage in Manaus: preliminary findings. Virological 2020(20-01-2021):https://virological.org/t/genomic-characterisation-of-an-emergentsars-cov-2-lineage-in-manaus-preliminary-findings $/ 586$.

8. Volz E, Mishra S, Chand M, Barrett JC, Johnson R, Geidelberg L, Hinsley WR, 
medRxiv preprint doi: https://doi.org/10.1101/2021.03.16.21253248; this version posted March 20, 2021. The copyright holder for this preprint (which was not certified by peer review) is the author/funder, who has granted medRxiv a license to display the preprint in perpetuity.

It is made available under a CC-BY-NC-ND 4.0 International license .

Laydon DJ, Dabrera G, O'Toole Á et al: Transmission of SARS-CoV-2 Lineage B.1.1.7 in England: Insights from linking epidemiological and genetic data. medRxiv 2021:2020.2012.2030.20249034.

9. European Centre for Disease Prevention and Control: Rapid increase of a SARS-CoV-2 variant with multiple spike protein mutations observed in the United Kingdom. 2020:1-13.

10. Felipe N, Valdinete N, Victor S, André C, Fernanda N, George S, Ágatha C, Débora D, Karina $P$, Luciana $G$ et al: Phylogenetic relationship of SARS-CoV-2 sequences from Amazonas with emerging Brazilian variants harboring mutations E484K and N501Y in the Spike protein. Virological 2021.

11. Washington NL, Gangavarapu K, Zeller M, Bolze A, Cirulli ET, Barrett KMS, Larsen BB, Anderson C, White S, Cassens $T$ et al: Genomic epidemiology identifies emergence and rapid transmission of SARS-CoV-2 B.1.1.7 in the United States. medRxiv 2021:2021.2002.2006.21251159.

12. Plante JA, Liu Y, Liu J, Xia H, Johnson BA, Lokugamage KG, Zhang X, Muruato AE, Zou J, Fontes-Garfias CR et al: Spike mutation D614G alters SARS-CoV-2 fitness. Nature 2020.

13. Zhou B, Thi Nhu Thao T, Hoffmann D, Taddeo A, Ebert N, Labroussaa F, Pohlmann A, King J, Steiner S, Kelly JN et al: SARS-CoV-2 spike D614G change enhances replication and transmission. Nature 2021.

14. Davies NG, Abbott S, Barnard RC, Jarvis Cl, Kucharski AJ, Munday J, Pearson CAB, Russell TW, Tully DC, Washburne $A D$ et al: Estimated transmissibility and severity of novel SARS-CoV-2 Variant of Concern 202012/01 in England. medRxiv 2021:2020.2012.2024.20248822.

15. Wibmer CK, Ayres F, Hermanus T, Madzivhandila M, Kgagudi P, Oosthuysen B, Lambson BE, de Oliveira T, Vermeulen M, van der Berg $\mathrm{K}$ et al: SARS-CoV-2 501Y.V2 escapes neutralization by South African COVID-19 donor plasma. Nat Med 2021.

16. Liu Z, VanBlargan LA, Bloyet LM, Rothlauf PW, Chen RE, Stumpf S, Zhao H, Errico JM, Theel ES, Liebeskind MJ et al: Identification of SARS-CoV-2 spike mutations that attenuate monoclonal and serum antibody neutralization. Cell Host Microbe 2021.

17. Greaney AJ, Starr TN, Gilchuk P, Zost SJ, Binshtein E, Loes AN, Hilton SK, Huddleston J, Eguia R, Crawford KHD et al: Complete Mapping of Mutations to the SARS-CoV-2 Spike Receptor-Binding Domain that Escape Antibody Recognition. Cell Host \& Microbe 2021, 29(1):44-57.e49. 
medRxiv preprint doi: https://doi.org/10.1101/2021.03.16.21253248; this version posted March 20, 2021. The copyright holder for this preprint (which was not certified by peer review) is the author/funder, who has granted medRxiv a license to display the preprint in perpetuity.

It is made available under a CC-BY-NC-ND 4.0 International license .

18. Wang Z, Schmidt F, Weisblum Y, Muecksch F, Barnes CO, Finkin S, Schaefer-Babajew D, Cipolla M, Gaebler C, Lieberman JA et al: mRNA vaccine-elicited antibodies to SARS-CoV-2 and circulating variants. Nature 2021.

19. Xie X, Liu Y, Liu J, Zhang X, Zou J, Fontes-Garfias CR, Xia H, Swanson KA, Cutler M, Cooper D et al: Neutralization of SARS-CoV-2 spike 69/70 deletion, E484K and N501Y variants by BNT162b2 vaccine-elicited sera. Nat Med 2021.

20. Wu K, Werner AP, Koch M, Choi A, Narayanan E, Stewart-Jones GBE, Colpitts T, Bennett $\mathrm{H}$, Boyoglu-Barnum S, Shi W et al: Serum Neutralizing Activity Elicited by mRNA-1273 Vaccine - Preliminary Report. New England Journal of Medicine 2021.

21. Hirotsu Y, Maejima M, Shibusawa M, Nagakubo Y, Hosaka K, Amemiya K, Sueki H, Hayakawa M, Mochizuki $\mathrm{H}$, Tsutsui $\mathrm{T}$ et al: Pooling RT-qPCR testing for SARS-CoV-2 in 1000 individuals of healthy and infection-suspected patients. Sci Rep 2020, 10(1):18899.

22. Hirotsu $Y$, Maejima M, Nakajima M, Mochizuki H, Omata M: Environmental cleaning is effective for the eradication of severe acute respiratory syndrome coronavirus 2 (SARS-CoV-2) in contaminated hospital rooms: A patient from the Diamond Princess cruise ship. Infect Control Hosp Epidemiol 2020, 41(9):1105-1106.

23. Shirato K, Nao N, Katano H, Takayama I, Saito S, Kato F, Katoh H, Sakata M, Nakatsu Y, Mori $Y$ et al: Development of Genetic Diagnostic Methods for Novel Coronavirus 2019 (nCoV-2019) in Japan. Jpn J Infect Dis 2020, 73(4):304-307

24. Hirotsu Y, Mochizuki H, Omata M: Double-quencher probes improve detection sensitivity toward Severe Acute Respiratory Syndrome Coronavirus 2 (SARS-CoV-2) in a reverse-transcription polymerase chain reaction (RT-PCR) assay $J$ Virol Methods 2020, 284:113926.

25. Omata M, Hirotsu $Y$, Sugiura H, Maejima M, Nagakubo Y, Amemiya K, Hayakawa M, Tsutsui T, Kakizaki $\mathrm{Y}$, Mochizuki $\mathrm{H}$ et al: The dynamic change of antibody index against Covid-19 is a powerful diagnostic tool for the early phase of the infection and salvage PCR assay errors. Journal of Microbiology, Immunology and Infection 2021.

26. Hirotsu Y, Omata M: Discovery of SARS-CoV-2 strain of P.1 lineage harboring $\mathrm{K} 417 \mathrm{~T}$ / E484K / N501Y by whole genome sequencing in the city, Japan. medRxiv 2021:2021.2002.2024.21251892.

27. Shepard SS, Meno S, Bahl J, Wilson MM, Barnes J, Neuhaus E: Viral deep 
sequencing needs an adaptive approach: IRMA, the iterative refinement meta-assembler. BMC Genomics 2016, 17:708.

28. Shu Y, McCauley J: GISAID: Global initiative on sharing all influenza data - from vision to reality. Euro Surveill 2017, 22(13).

29. Hadfield J, Megill C, Bell SM, Huddleston J, Potter B, Callender C, Sagulenko P, Bedford T, Neher RA: Nextstrain: real-time tracking of pathogen evolution. Bioinformatics 2018, 34(23):4121-4123.

30. Rambaut A, Holmes EC, O'Toole A, Hill V, McCrone JT, Ruis C, du Plessis L, Pybus OG: A dynamic nomenclature proposal for SARS-CoV-2 lineages to assist genomic epidemiology. Nat Microbiol 2020, 5(11):1403-1407.

31. COVID-19 vaccines: acting on the evidence. Nature Medicine 2021, 27(2):183-183.

32. Chen RE, Zhang X, Case JB, Winkler ES, Liu Y, VanBlargan LA, Liu J, Errico JM, Xie X, Suryadevara $\mathrm{N}$ et al: Resistance of SARS-CoV-2 variants to neutralization by monoclonal and serum-derived polyclonal antibodies. Nature Medicine 2021.

33. Zhou D, Dejnirattisai W, Supasa P, Liu C, Mentzer AJ, Ginn HM, Zhao Y, Duyvesteyn HME, Tuekprakhon A, Nutalai R et al: Evidence of escape of SARS-CoV-2 variant B.1.351 from natural and vaccine induced sera. Cell 2021.

34. Lasek-Nesselquist E, Lapierre P, Schneider E, George KS, Pata J: The localized rise of a B.1.526 SARS-CoV-2 variant containing an E484K mutation in New York State. medRxiv 2021:2021.2002.2026.21251868.

35. Annavajhala MK, Mohri H, Zucker JE, Sheng Z, Wang P, Gomez-Simmonds A, Ho DD, Uhlemann A-C: A Novel SARS-CoV-2 Variant of Concern, B.1.526, Identified in New York. medRxiv 2021:2021.2002.2023.21252259.

36. Wise J: Covid-19: The E484K mutation and the risks it poses. BMJ 2021, 372:n359. 